\title{
PENINGKATAN KINERJA SISWA MELALUIPENDEKATAN SAINTIFIK PADA PEMBELAJARAN IPA TERPADUMODEL WEBBED
}

\section{IMPROVE STUDENT PERFORMANCE THROUGH A SCIENTIFIC APPROACH IN INTEGRATED SCIENCE TEACHING MODELS WEBBED PERFORMED}

\author{
Risdalina, Siti Sriyati dan Setiya Utari \\ Universitas Pendidikan Indonesia \\ E-mail: risdalina@gmail.com
}

\begin{abstract}
ABSTRAK
Penelitian dengan tujuan meningkatkan kinerja siswa melalui pendekatan saintifik dalam pembelajaran IPA terpadu model webbed dilakukan di salah satu SMP Negeri di Kota Bandung dengan menggunakan sampel 25 orang siswa yang dipilih secara cluster random sampling. Kinerja siswa adalah gambaran kemampuan siswa dalam menyelesaikan tugas-tugas spesifik yang diberikan oleh guru dan dapat diukur berdasarkan kriteria yang telah ditentukan. Untuk menilai kinerja siswa digunakan Lembar Kerja Siswa sebagai instrumen yang dinilai dengan rubrik gradasi penilaian kinerja. Penelitian ini menggunakan metode rancangan weak experimental dengan desain the one-shot case study. Kinerja rata-rata siswa berturut turut dari pertemuan pertama, kedua dan ketiga adalah 66.52, 75.32 dan 82.68 dianalisis dengan paired t-test memperoleh nilai signifikansi 0,000. Data temuan kinerja siswa tertinggi adalah mengajukan pertanyaan dan kinerja siswa terendah adalah merencanakan percobaan. Kata kunci: pendekatan saintifik, IPA terpadu, kinerja siswa
\end{abstract}

\begin{abstract}
This research aimed to improve student performance through a scientific approach in webbed-based integrated science teaching. It was held in one Junior High School in Bandung by using a sample of 25 students who were selected by cluster random sampling technique. Student performance reflects their ability in solving specific tasks given by the teacher, and it can be measured by predetermined criteria. To assess student performance, this study used Student Worksheet as its instrument which was rated by rubric grading performance assessment. This study uses a weak experimental design with the design of the one-shot case study. The average performance of students for the first to third meeting were 66.52, 75.32 and 82.68. This data was analyzed using paired t-test and gained significant value of 0.000. Data showed that the highest student performance came from asking question, and the lowestwasfrom experiment planning category.
\end{abstract}

Keywords: scientific approach, integrated science, students' performance

\section{PENDAHULUAN}

Kinerja menurut Koesmono (2013); Brahmasari \& Suprayetno(2013); Harlie (2012); Riyadi(2013); Sofyan(2013) adalah suatu gambaran tentang diri seseorang dengan berbagai standar tugas yang telah diberikan kepada orang tersebut sebagai salah satu bentuk tanggung jawab dalam kurun waktu tertentu dan dapat diukur. Popham (2015) mengemukakan bahwa" Performance assessment is approach to measuring a student's status based on the way that the student completes a specified task". Penilaian kinerja mengukur kemampuan siswa berdasarkan cara siswa menyelesaikan tugas tertentu.Dari definisi tersebut, dapat dinyatakan bahwa kinerja siswa merupakan gambaran kemampuan siswa dalam menyelesaikan tugas-tugas spesifik yang diberikan oleh guru dan dapat diukur berdasarkan kriteria yang telah ditentukan.

Kinerja merupakan hal yang penting untuk dilatihkan dalam pembelajaran IPA, karena standar kompetensi lulusan tidak hanya menuntut dari sisi kemampuan kognitif saja, melainkan juga keterampilan. Dari sisi keterampilan, standar kompetensi lulusan menuntut siswa memiliki kemampuan pikir dan tindak yang efektif dan kreatif dalam ranah abstrak dan konkret sesuai dengan yang dipelajari di sekolah dan sumber lain sejenis (Kebudayaan, 2013). 
Hakikatnya IPA meliputi empat unsur, yaitu: (1) produk: berupa fakta, prinsip, teori, dan hukum; (2) proses: yaitu prosedur pemecahan masalah melalui metode ilmiah; metode ilmiah meliputi pengamatan, penyusunan hipotesis, perancangan eksperimen, percobaan atau penyelidikan, pengujian hipotesis melalui eksperimentasi; evaluasi, pengukuran, dan penarikan kesimpulan; (3) aplikasi: merupakan penerapan metode atau kerja ilmiah dan konsep IPA dalam kehidupan sehari-hari; (4) sikap: yang terwujud melalui rasa ingin tahu tentang obyek, fenomena alam, makhluk hidup, serta hubungan sebab akibat yang menimbulkan masalah baru namun dapat dipecahkan melalui prosedur yang benar. (Departemen Pendidikan Nasional, 2007). Proses sains pada hakikat IPA yang merupakan prosedur pemecahan masalah melalui metode ilmiah penting untuk diterapkan dalam pembelajaran IPA, karena hal ini dapat melatih keterampilan proses siswa yang dapat diukur menjadi kinerja siswa.

Temuan di lapangan, guru jarang sekali menerapkan pembelajaran yang dapat melatihkan kinerja siswa. Siswa jarang dilibatkan dalam kegiatan percobaan atau praktikum, padahal fasilitas praktikum mulai dari alat dan bahan di sekolah ini cukup memadai. Hal ini menyebabkan kurang terlatihnya kinerja siswa.

Dari permasalahan tersebut, diperlukan upaya untuk menciptakan suatu pembelajaran yang dapat melatih kinerja siswa. Salah satu pendekatan pembelajaran yang dipandang efektif untuk melatih kedua hal tersebut adalah pendekatan saintifik. Langkah-langkah pendekatan saintifik yang berupa mengamati, menanya, mengumpulkan informasi, mengasosiasi, mengkomunikasikan merupakan langkah-langkah penting yang berkaitan dengan keterampilan proses yang dapat melatih kinerja siswa.Hasil penelitian Marjan, Arnyana, \& Si(2014); Usmeldi (2016); Prabowo(2015) menyatakan bahwa pembelajaran dengan pendekatan saintifik dapat meningkatkan keterampilan proses sains siswa.

Pada penelitian kali ini,pendekatan saintifik dipadukan dengan pembelajaran IPA terpadu sesuai amanat KTSP dan Kurikulum 2013. Pembelajaran terpadu dalam IPA dapat dikemas dengan tema atau topik tentang suatu wacana yang dibahas dari berbagai aspek bidang kajian IPA (Departemen Pendidikan Nasional, 2010). Dewi, Sadia, \& Ristiati(2013); Rahayu, Mulyani, \& Miswadi(2012) menyatakan bahwa pembelajaran IPA terpadu dapat meningkatkan keterampilan kinerja ilmiah siswa.

Terdapat 10 Tipe model-model pembelajaran terpadu yang dikemukakan oleh Fogarty(2013) yaitu Model Fragmented, Model Connected, Model Nested, Model Sequenced, Model Shared, Model Webbed. Model Threaded, Model Integrated, Model Immersed, dan ModelNetworked. Tiga diantaranya sesuai untuk dikembangkan dalam pembelajaran IPA ditingkat pendidikan di Indonesia. Ketiga model yang dimaksud adalah model keterhubungan (connected), model jaring laba-laba (webbed), dan model keterpaduan (integrated) (Departemen Pendidikan Nasional, 2010). Model Webbedmerupakan pembelajaran yang pengembangannya dimulai dengan menentukan tema tertentu yang menjadi tema sentral bagi keterhubungan berbagai bidang studi (Fogarty, 2013). Tema menurut Trianto(2012)dapat dikembangkan menjadi sub-sub tema dengan memperhatikan kaitannya dengan bidang-bidang studi, dari sub-sub tema ini dikembangkanlah aktivitas belajar siswa.

Dalam menentukan tema sentral dalam model webbed ini, akan melihat kondisi keadaan yang dekat dengan siswa seharihari. Berdasarkan pengkajian terhadap kompetensi dasar kurikulum 2013 kelas VII semester satu, diperoleh tema Energi dalam Kehidupan. Energi dianggap dekat 
dengan kehidupan siswa sehari-hari, karena dalam melakukan segala aktivitasnya siswa membutuhkan energi. Siswa membutuhkan energi, tidak hanya untuk aktivitasnya, tetapi pada usia remaja kalori juga dibutuhkan untuk pertumbuhan. Setiap orang ternyata memiliki sejumlah kalori sehari-hari yang harus dipenuhinya setiap hari, tidak lebih dan tidak pula kurang.Sartika(2012) menyatakan persoalan akan muncul jika anak pada usia remaja kelebihan kalori, akan menyebabkan penimbunan lemak, bahkan obesitas dan pada usia remaja awal (0-14 tahun) sangat rentan terhadap masalah kurang atau lebihnya gizi. Oleh karena itu, tema energi dalam kehidupan dianggap tepat untuk diajarkan pada siswa SMP yang pada usia mereka sangat membutuhkan informasi ini.

\section{METODE PENELITIAN}

Penelitian ini bertujuan untuk melihat peningkatan skor kinerja siswa selama proses pembelajaran. Penelitian ini hanya menggunakan satu grup sampel penelitian, kelas kontrol tidak diperlukan karena hanya meneliti pengaruh variable bebas terhadap variable terikat. Metode penelitian yang digunakan pada penelitian ini adalah metode penelitian Eksperimen dengan jenis weak experimentaldengan desain the one-shot case study design. Dalam rancangan ini, hanya ada satu kelompok yang dikenai perlakuan, dan variabel terikatnya langsung diamati (diukur) untuk menilai efektivitas dari perlakuan(Jack R. Fraenkel \& Norman E. Wallen, 2015)

Tabel 1

Desain penelitian the one-shot case study design

\begin{tabular}{ccc}
\hline Group I & $\mathrm{X}$ & $\mathrm{O}$ \\
\hline & Perlakuaan & Observasi \\
\hline
\end{tabular}

Keterangan :

$\mathrm{X}$ : Pembelajaran IPA terpadu model webbed tema energi dalam kehidupan dengan pendekatan saintifik

O : Observasi Kinerja Siswa. Populasi yang diambil adalah siswa kelas VII salah satu SMP Negeri di Kota Bandung.

Berdasarkan data yang diperoleh dari guru, tingkat kemampuan masing- masing kelas sama rata. Penelitian hanya membutuhkan satu kelas sampel, dan tidak memungkinkan memilih individu-individu untuk dikelompokkan dalam satu kelas, maka kelas yang akan diteliti dipilih menggunakan cluster random sampling(Jack R. Fraenkel \& Norman E. Wallen, 2015). Sampel yang terpilih adalah kelas VII H. Seluruh siswa kelas VII H berjumlah 34 orang, tetapi secara bergantian tidak hadir selama pembelajaran berjumlah 8 orang. Jadi jumlah sampel berkurang menjadi 25 orang.

Instrumen yang digunakan dalam penelitian kali ini adalah Lembar Kerja Siswa (LKS) pembelajaran IPA terpadu model webbed tema energi dalam kehidupan. Tema ini dibagi dalam tiga subtema yaitu respirasi, fotosintesis dan energi dari makanan dengan masing-masing satu LKS. Masing-masing subtema ini diajarkan satu kali pertemuan. LKS ini akan digunakan untuk menilai kinerja siswa berdasarkan rubrik gradasi penilaian kenerja yang dikembangkan berdasarkan indikator keterampilan prosessains(KPS) oleh (Rustaman, 2012). Indikator KPS tidak digunakan seluruhnya, tetapi hanya dibatasi pada observasi, interpretasi, mengajukan pertanyaan, mengajukan hipotesis, merencanakan percobaan, mengklasifikasi, menerapkan konsep dan berkomunikasi.

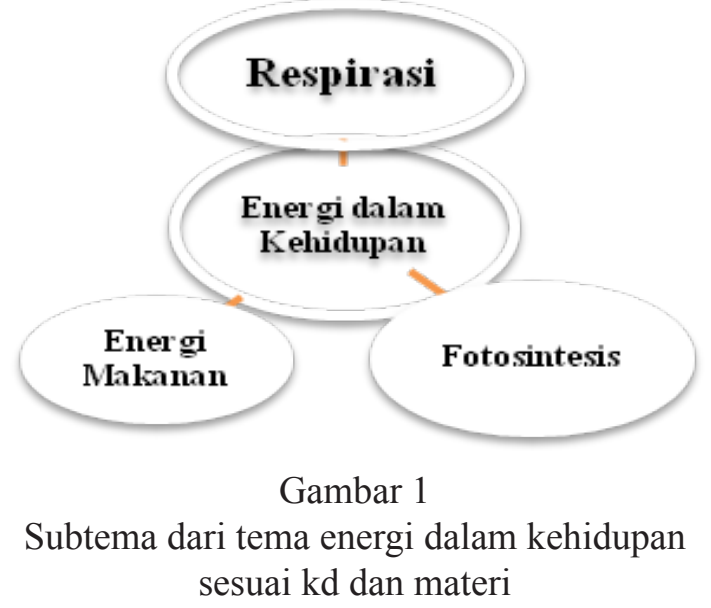

Skor kinerja siswa yang diperoleh berdasarkan rubrik gradasi penilaian kinerja, dikonversi ke angka 0-100.Analisis data yang digunakan untuk melihat peningkatan 
kinerja siswa adalah uji paired t-test jika data berdistribusi normal dan, digunakan uji wilcoxon sign test apabila data tidak berdistribusi normal dan tidak homogen.

\section{HASIL PENELITIAN DAN PEMBAHASAN}

Pada pertemuan pertama tema energi dalam kehidupan subtema respirasi digunakan indikator kunci sebanyak 13 butir, pada pertemuan kedua subtema fotosintesis digunakan indikator kunci sebanyak 8 butir, dan pertemuan ketiga subtema energi dari makanan digunakan indikator kunci sebanyak 13 butir. Indikator-indikator ini digunakan untuk menilai kinerja siswa yang dituangkan ke dalam Lembar Kerja Siswa (LKS). Penilaian kinerja dilakukan secara individual dengan menilai masing-masing LKS siswa, tidak dengan cara penilaian kelompok.

Tabel 2

Hasil skor kinerja

\begin{tabular}{|c|c|c|c|c|c|c|c|c|}
\hline \multirow{2}{*}{ No } & \multirow{2}{*}{ Tes } & \multicolumn{3}{|c|}{ Skor } & \multirow{2}{*}{ Uji Normalitas } & \multirow{2}{*}{ Uji Homogenitas } & \multicolumn{2}{|c|}{ Uji Paired t-test } \\
\hline & & $X \min$ & $\mathrm{Xmax}$ & $\bar{X}$ & & & Sign. & $\mathrm{t}$ \\
\hline 1 & LKS Respirasi & 51 & 77 & 66.52 & Normal & \multirow{4}{*}{0.520} & $1 \& 2$ & $1 \& 2$ \\
\hline 2 & LKS Fotosintesis & 63 & 83 & 75.32 & Normal & & 0.000 & -6.633 \\
\hline \multirow[t]{2}{*}{3} & LKS Energi dari & 69 & 92 & 82.68 & Normal & & $2 \& 3$ & $2 \& 3$ \\
\hline & Makanan & & & & & & 0.000 & -7.218 \\
\hline
\end{tabular}

Rata-rata skor kinerja siswa berdasarkan Tabel 2 terlihat meningkat mulai dari pertemuan pertema hingga pertemuan ketiga berturut-turut 66.52, 75.32 dan 82.68. Untuk mengetahui bahwa data itu berbeda signifikan atau tidak, maka dilakukan uji statistik Setelah diuji normalitas dan homogenitas dan didapatkan hasil bahwa data berdistribusi normal dan varians data homogen, maka dilanjutkan dengan uji hipotesis menggunakan statistik parametrik uji paired t-test menggunakan aplikasi SPSS
16.0. Hasil uji peningkatan rata-rata skor kinerja pada pertemuan pertama dengan pertemuan kedua pada taraf kepercayaan 95\% memperoleh signifikansi 0,000. Hasil uji peningkatan rata-rata skor kinerja pada pertemuan kedua dan pertemuan ketiga memperoleh signifikansi 0,000. Hal ini menunjukkan bahwa pada tingkat kepercayaan 95\%, pembelajaran dengan pendekatan saintifik dalam pembelajaran IPA terpadu berpengaruh terhadap peningkatan skor kinerja siswa.

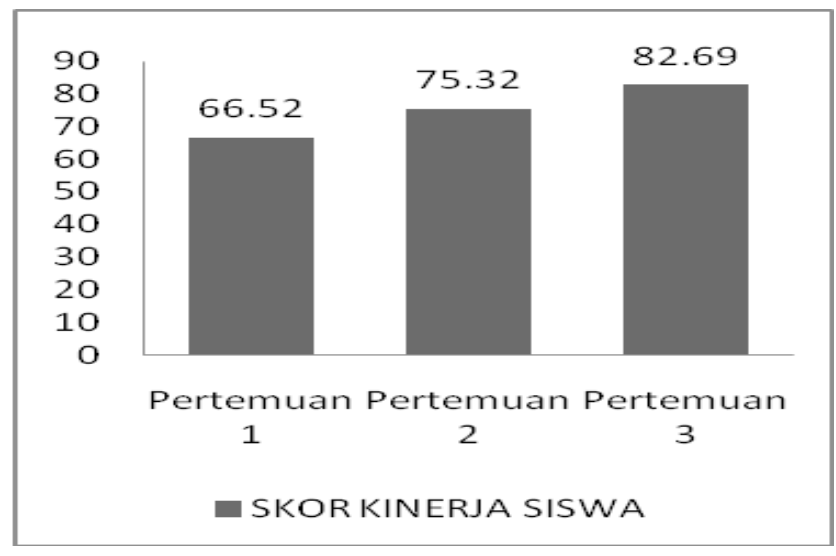

Gambar 2

Histogram kinerja siswa

Pada penelitian ini indikator kinerja yang digunakan adalah indikator keterampilan proses sains. Penelitian yang senada dengan hasil penelitian ini adalah hasil penelitian
Marjan et al.(2014); Prabowo(2015); Usmeldi(2016) menyatakan bahwa pembelajaran dengan pendekatan saintifik dapat meningkatkan keterampilan proses 
sains siswa. Selain itu, salah satu karakter pendekatan saintifik menurut Lazim (2013:2) adalah melibatkan keterampilan proses sains dalam mengkonstruksi konsep, hukum atau prinsip.

Penelitian kali ini memadukan antara pendekatan saintifik dengan pembelajaran IPA terpadu. Hasil penelitian Dewi et al. (2013) bahwa pembelajaran IPA terpadu dapat meningkatkan kinerja ilmiah siswa. Hal ini selaras dengan temuan yang dilakukan oleh peneliti.

Tabel 2

Rekapitulasi kinerja siswa untuk setiap indikator

\begin{tabular}{lcccc}
\hline \multirow{2}{*}{\multicolumn{1}{c}{ Indikator }} & \multicolumn{3}{c}{ Pertemuan } & Gain \\
\cline { 2 - 5 } & I & II & III & $1 \&$ III \\
\hline Observasi & 72 & 86.7 & 90.7 & 18.7 \\
\hline Interpretasi & 62.2 & 54.7 & 67.1 & 4.89 \\
\hline Mengajukan pertanyaan & 54.7 & 66.7 & 97.3 & 42.7 \\
\hline Mengajukan Hipotesis & 50.7 & 54.7 & 61.3 & 10.7 \\
\hline Merencanakan Percobaan & 72 & 88 & 76 & 4 \\
\hline Berkomunikasi & 70.7 & 82.7 & 95.3 & 24.7 \\
\hline Mengklasifikasi & - & - & 90.7 & 90.7 \\
\hline Menerapkan Konsep & - & - & 85.3 & 85.3 \\
\hline
\end{tabular}

Urutan kinerja rata-rata yang mengalami peningkatan mulai dari yang terendah hingga tertinggi berdasarkan Tabel 2 adalah merencanakan percobaan, interpretasi, berhipotesis, observasi, berkomunikasi, menerapkan konsep, mengklasifikasi, menanya. Hal ini dikarenakan langkahlangkah pembelajaran pendekatan saintifik yang meliputi mengamati, menanya, mengumpulkan informasi, mengasosiasi dan mengkomunikasikan sangat sesuai dan dapat melatihkan keterampilan proses sains yang dijadikan indikator kinerja siswa. Oleh karena itu pendekatan saintifik ini sangat baik digunakan dalam meningkatkan kinerja siswa terutama yang berkaitan dengan keterampilan proses sains. Hasil penelitian Fauziah, Abdullah, \& Hakim(2013) menyatakan bahwa tahap-tahap pendekatan saintifik dapat meningkatkan kemampuan peserta didik dalam mengamati, menanya, menalar, mencoba dan mengkomunikasikan temuannya, sehingga berdampak positif terhadap kemampuan soft skill-nya.

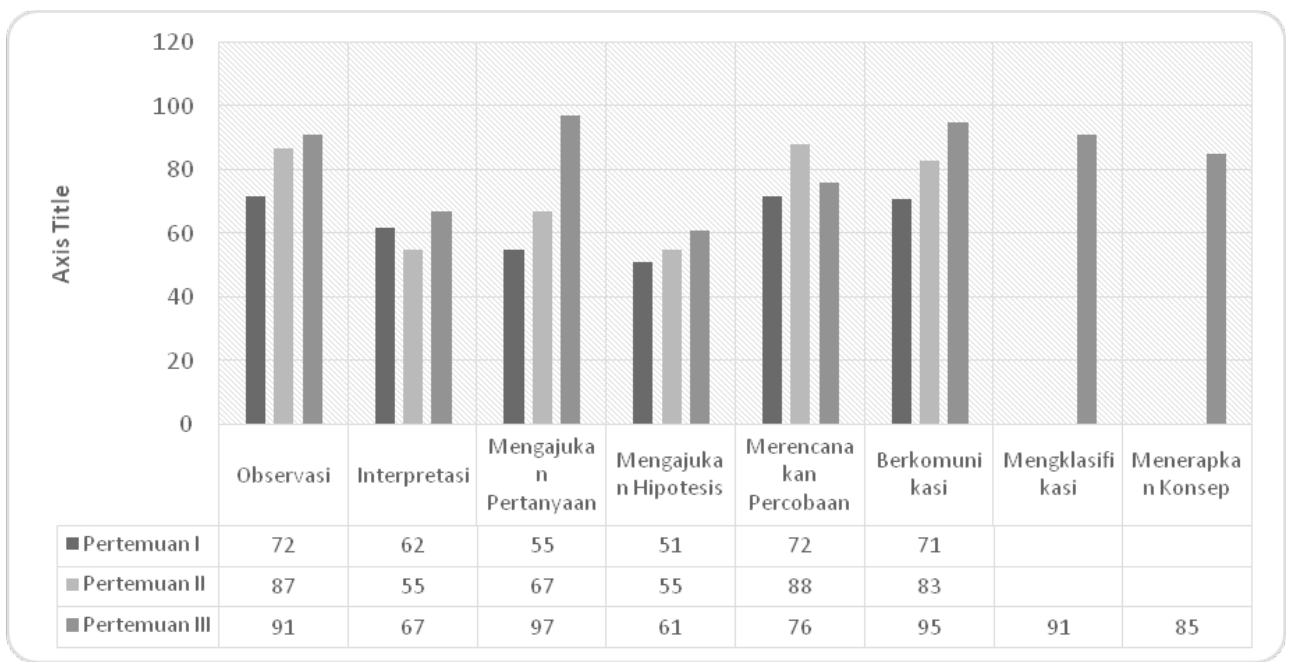

Gambar 3

Histogram kinerja rata-rata siswa untuk setiap indikator

Penelitian lain yang mendukung penelitian ini adalah penelitian Wijayanti(2014) menyatakan bahwa pembelajaran yang dirancang dengan memanfaatkan asesmen 
autentik berbasis proyek berpendekatan saintifik efektif meningkatkan keterampilan berpikir ilmiah siswa yang meliputi merumuskan masalah, merumuskan hipotesis, menghimpun data, dan menyelesaikan masalah. Asesmen autentik pada penelitian Wijayanti(2014) dilaksanakan dengan memberikan tugas-tugas dan menilai siswa berdasarkan tugas tersebut. Hal ini tidak jauh berbeda dengan penelitian yang dilakukan oleh peneliti terhadap penilaian kinerja siswa. Siswa diberikan tugas-tugas kinerja yang akan dinilai menggunakan rubrik penilaian kinerja.

Pembelajaran kali ini juga menerapkan praktikum dalam pembelajarannya, hal ini juga mempengaruhi peningkatan kinerja siswa. Hal ini senada dengan hasil penelitian yang dilakukan oleh Sudesti, Sudargo, \& K(2014) yang menyatakan bahwa pembelajaran berbasis praktikum mempengaruhi keterampilan proses sains siswa.

\section{SIMPULAN}

Hasil penelitian menunjukkan bahwa terjadi peningkatan kinerja siswa dari pertemuan pertama, kedua dan ketiga. Berdasarkan hasil tersebut dapat disimpulkan bahwa terjadi peningkatan kinerja siswa melalui pendekatan saintifik dalam pembelajaran IPA terpadu. Kinerja yang mengalami peningkatan paling tinggi adalah mengajukan pertanyaan dan kinerja mengalami peningkatan paling rendah adalah merencanakan percobaan.

\section{REKOMENDASI}

Berdasarkan hasil penelitain, dapat direkomendasikan bahwa pendekatan saintifik dapat meningkatkan kinerja siswa terlebih dalam pembelajaran IPA terpadu. Hal ini karena pendekatan saintifik efektif meningkatkan keterampilan berpikir ilmiah siswa yang meliputi merumuskan masalah, merumuskan hipotesis, menghimpun data, dan menyelesaikan masalah. Pendekatan saintifikjugadapatmeningkatkankemampuan peserta didik dalam mengamati, menanya, menalar, mencoba dan mengkomunikasikan temuannya, sehingga berdampak positif terhadap kemampuan soft skill-nya.

\section{DAFTAR RUJUKAN}

Brahmasari, I., \& Suprayetno, A. (2013). Pengaruh Motivasi Kerja, Kepemimpinan dan Budaya Organisasi Terhadap Kepuasan Kerja Karyawan serta Dampaknya pada Kinerja Perusahaan. Jurnal Manajemen Dan Kewirausahaan, 10(2), 124-135.

Departemen Pendidikan Nasional. (2007). Kajian Kebijakan Kurikulum Mata Pelajaran IPA (p. 699). Jakarta: Puskur Balitbang Depdiknas.

Departemen Pendidikan Nasional. (2010). Panduan Pengembangan Pembelajaran IPA Secara Terpadu. Jakarta: Puskur Balitbang Depdiknas.

Dewi, K., Sadia, W., \& Ristiati, N. (2013). Pengembangan perangkat pembelajaran ipa terpadu dengan setting inkuiri terbimbing untuk meningkatkan pemahaman konsep dan kinerja ilmiah siswa. Jurnal Pendidikan IPA, 3(1), 1-11.

Fauziah, R., Abdullah, A., \& Hakim, D. (2013). Pembelajaran saintifik elektronika dasar berorientasi pembelajaran berbasis masalah. Jurnal Invotec, 9(2), 165-178.

Fogarty, R. (2013). How to integrate the curricula. New York: Skylight Publishing Inc.

Harlie, M. (2012). Pengaruh Disiplin Kerja, Motivasi dan Pengembangan Karier terhadap Kinerja Pegawai Negeri Sipil pada Pemerintah Kabupaten Tabalong di Tanjung Kalimantan. Jurnal Aplikasi Manajemen, 11(2), 117-124.

Jack R. Fraenkel, \& Norman E. Wallen. (2015). How to Design and Evaluate Research in Education 7th Edition: Jack R. Fraenkel (J.R. Fraenkel) / Norman E. Wallen (N.E. Wallen): Amazon.com: Books. New York: The McGraw-Hill Companies, Inc. 
Kebudayaan, K. P. dan. (2013). Lampiran Peraturan Menteri Pendidikan dan Kebudayaan Nomor 54 Tahun 2013 Tentang Standar Kompetensi Lulusan. Jakarta: Kemendikbud.

Koesmono, H. (2013). Pengaruh budaya organisasi terhadap motivasi dan kepuasan kerja serta kinerja karyawan pada sub sektor industri pengolahan kayu skala menengah di jawa timur. Jurnal Manajemen Dan Kewirausahaan (Journal of, 7(2), 171-188.

Lazim, M. (2013). Penerapan Pendekatan Saintifik dalam Pembelajaran Kurikulum 2013. Jurnal Pendidikan, 1(2), 13-22.

Marjan, J., Arnyana, I., \& Si, M. (2014). Pengaruh Pembelajaran Pendekatan Saintifik Terhadap Hasil Belajar Biologi Dan Keterampilan Proses Sains Siswa MA. Mu allimat NW Pancor Selong Kabupaten. Jurnal Pendidikan, 3(1), 101-109.

Popham, J. (2015). Classroom Assessment : What Teacher Need to Know (Sixth Edition): Books (Boston). Pearson.

Prabowo, S. (2015). The effectiveness of scientific based learning towards science process skill mastery of PGSD students. Jurnal Pendidikan IPA Indonesia, 4(1), 15-19.

Rahayu, P., Mulyani, S., \& Miswadi, S. (2012). Pengembangan Pembelajaran IPA Terpadu dengan Menggunakan Model Pembelajaran Problem Base Melalui Lesson Study. Jurnal Pendidikan IPA, 1(1), 63-70.

Riyadi, S. (2013). Pengaruh Kompensasi Finansial, Gaya Kepemimpinan, dan Motivasi Kerja Terhadap Kinerja Karyawan pada Perusahaan Manufaktur di Jawa Timur. Jurnal Manajemen Dan Kewirausahaan (Journal of, 13(1), 40-45.

Rustaman, N. (2012). Keterampilan Proses Sains. Jurnal Pendidikan, 1(1), 1-12.

Sartika, R. (2012). Faktor risiko obesitas pada anak 5-15 tahun di Indonesia. Makara Kesehatan, 15(1), 37-43.

Sofyan, D. (2013). Pengaruh Lingkungan Kerja Terhadap Kinerja Kerja Pegawai BAPPEDA. Malikussaleh Industrial Engineering Journal, 2(1), 18-23.

Sudesti, R., Sudargo, F., \& K, M. N. (2014). Penerapan Pembelajaran Berbasis Praktikum Untuk Meningkatkan Penguasaan Konsep Dan Keterampilan Proses Sains Siswa Smp Pada Subkonsep Difusi Osmosis. Formica Education Online, 1(1), 13-23.

Trianto. (2012). Model Pembelajaran Terpadu: Konsep, Strategi, dan Implementasi dalam Kurikulum Tingkat Satuan Pendidikan (KTSP). Jakarta: Bumi Aksara.

Usmeldi, U. (2016). The Development Of Research-Based Physics Learning Model With Scientific Approach To Develop Students'scientific Processing. Jurnal Pendidikan IPA Indonesia, 5(1), 134-139.

Wijayanti, A. (2014). Pengembangan autentic assesment berbasis proyek dengan pendekatan saintifik untuk meningkatkan keterampilan berpikir ilmiah mahasiswa. Jurnal Pendidikan IPA Indonesia, 3(2), 102108. 